\title{
HIGH-RESOLUTION MARINE GEOLOGIC MAPS SHOWING SEDIMENT DISTRIBUTION ON THE INSULAR SHELF OFF LUQUILLO, PUERTO RICO
}

\author{
By William C. Schwab ${ }^{1}$, Rafael W. Rodríguez ${ }^{2}$, William W. Danforth ${ }^{1}$, Marguerite H. Gowen ${ }^{3}$, \\ E. Robert Thieler ${ }^{4}$, and Thomas F. O'Brien ${ }^{1}$
}

1996

\section{INTRODUCTION}

The shallow marine shelf surrounding the Commonwealth of Puerto Rico has an area of about $3,500 \mathrm{~km}^{2}$ within the $200 \mathrm{~m}$ isobath, or nearly two-thirds that of the land area of the island. Deposits of sand and gravel on the insular shelf are of major importance to Puerto Rico because of their potential for low-cost development and because suitable onshore sources have been depleted. On an island where more than 85 percent of the population lives within $7 \mathrm{~km}$ of the sea and is dependent on the tourism that its beaches attract, it is necessary that scientific data related to oceanographic processes acting in the coastal zone and on the insular shelf be available to help formulate public policy regarding residential and commercial development along the coast, beach replenishment, and future utilization of marine resources.

Hurricane Hugo struck Puerto Rico on September 18, 1989, with maximum sustained winds of $225 \mathrm{~km} / \mathrm{hr}$ and a minimum sea-level pressure of $934 \mathrm{mb}$ causing extensive damage to the coastal infrastructure (Rodríguez and others, 1994). Studies were conducted to assess the effects of the hurricane (hereafter referred to as Hugo) on three critical coastal resources: beaches, offshore sand deposits, and coral reefs (Schwab and Rodríguez, 1992). In this report, we present the findings of high-resolution sea-floor mapping investigations related to the Hugo study conducted on the northern insular shelf, offshore of the town of Luquillo (fig. 1).

The Luquillo study area lies directly in the path that Hugo followed (fig. 2). A combination of storm-induced waves and sealevel surge caused minor to moderate erosion of the beaches in the Luquillo area (Rodríguez and Webb, 1990). Considering the intensity of Hurricane Hugo, the impact on coastal erosion rates was surprisingly limited. However, historical shoreline-change data shows that some shoreline segments in the vicinity of Luquillo were eroded during the past 50 years (Thieler, 1993). In an attempt to determine the ultimate fate of sediment removed from the coastal zone, detailed sea-floor mapping was conducted using high-resolution sidescan-sonar, and seismic-reflection techniques followed by bottom sediment sampling and sedimentologic analysis. Prior to these investigations, it was generally unknown where the sand eroded from the coast by major storms had gone, or if the material was recoverable.

\footnotetext{
Manuscript approved for publication September 1, 1994

'U.S. Geological Survey, Woods Hole, Massachusetts.

${ }^{2}$ U.S. Geological Survey, San Juan, Puerto Rico.

${ }^{3}$ U.S. Geological Survey, Menlo Park, California.

${ }^{4}$ Duke University, Durham, North Carolina.
}

\section{STUDY AREA}

Reconnaissance sea-floor mapping studies based on widely spaced seismic-reflection data and bottom samples have shown that the sediment cover on the narrow insular shelf around Puerto Rico is patchy and diverse with little lateral continuity (for example, Pilkey and others, 1987). This sediment-cover variability is thought to be a reflection of the wide range of physical and biological factors affecting sedimentation on this low-latitude insular margin (Schneidermann and others, 1976). The steep and narrow nature of the northern insular shelf and its exposure to high-energy wave conditions are thought to promote rapid cross-shelf sediment transport (Pilkey and others, 1978; Grove and others, 1982; Pilkey and others, 1984).

The insular shelfbreak in the Luquillo study area occurs at a water depth of about $70 \mathrm{~m}$ and borders the landward slope of the Puerto Rico trench. The shelf off Luquillo ranges in width between 4 and $10 \mathrm{~km}$ and has a slope that is steep (0.3 to $\left.0.7^{\circ}\right)$ in comparison to typical continental shelves. The bathymetry of the study area is relatively irregular due to outcropping Pleistocene eolianite as described by Kaye (1959). Two well-developed submarine canyon systems extend far onto the shelf in the study area, one off the mouth of the river Río Mameyes and another $4 \mathrm{~km}$ to the east (fig. 1). The most important factors affecting sedimentation in the Luquillo study area are thought to be shelf bathymetry, wave energy, and coral reefs and other rock outcrops on the sea floor.

Historical vertical aerial photographs of the Puerto Rico shoreline were examined using the methodology outlined in Danforth and Thieler (1992a,b) for the purpose of delineating shoreline change from the period of 1901 to 1987 (Thieler, 1993). Although the temporal component of the data varies in the Luquillo study area (Thieler and Danforth, 1993), a general trend of minor erosion on the northwest side of the headlands with accretion on the southeast sides has occurred on Punta Miquillo, Punta Picúa, and possibly Punta Embarcadero (fig. 3). The shoreline of the embayment between Punta Percha and Punta Embarcadero is eroding at rates as high as $2 \mathrm{~m} / \mathrm{yr}$ while the shoreline along the embayment between the town of Luquillo and Cabeza Chiquita is, in general, eroding at rates of 1 to $2 \mathrm{~m} / \mathrm{yr}$ on the west side and accreting at similar rates on the east side (fig. 3). The relative importance of the longshore versus offshore components of sediment transport in these shoreline change rates is unknown.

Although Puerto Rico lies within the plate boundary zone between the North American and Caribbean plates, an area of high seismicity and tectonic activity (Sykes and others, 1982; Mann and Burke, 1984), evidence of active faulting was not recognized during this study. 


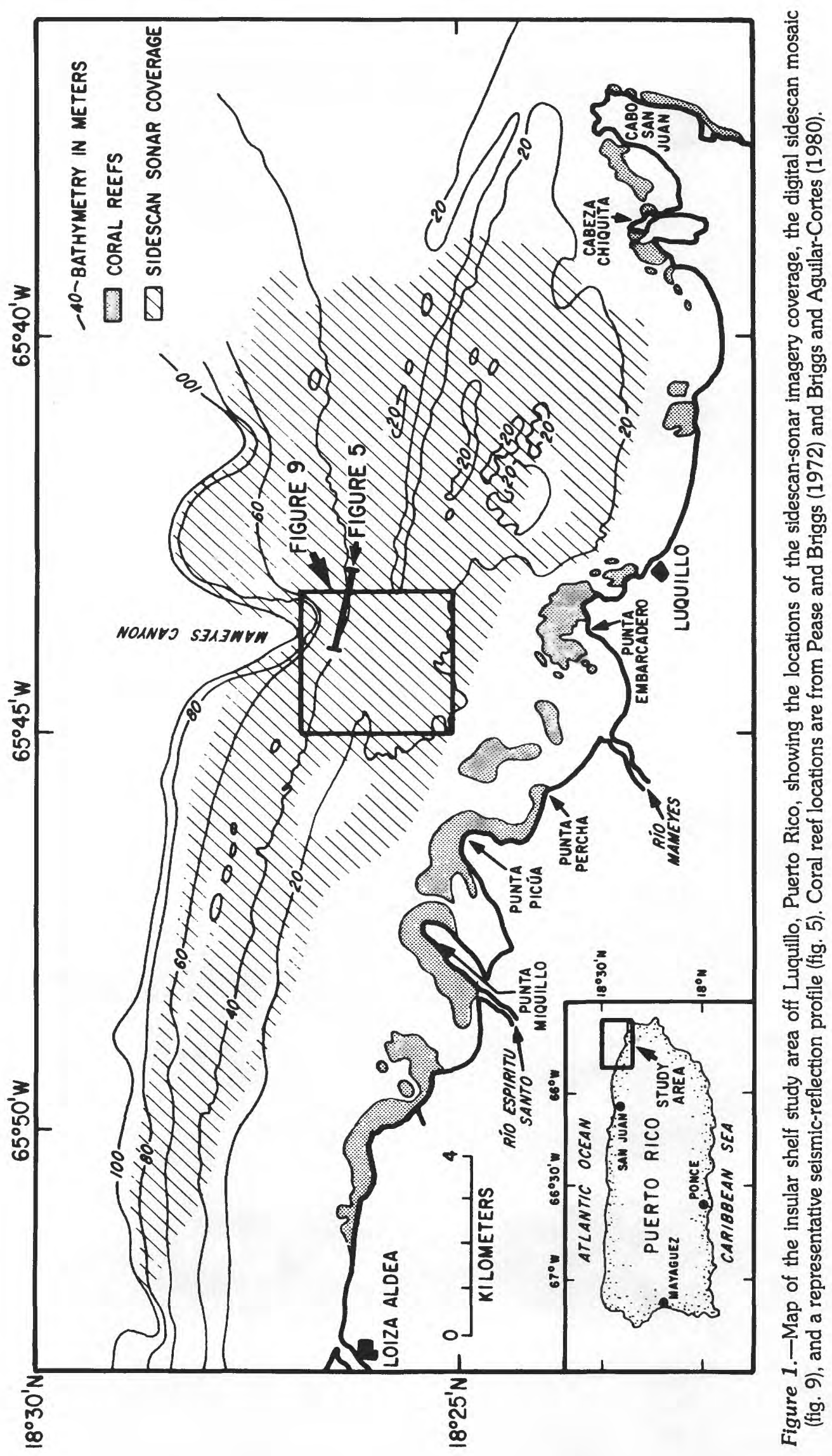




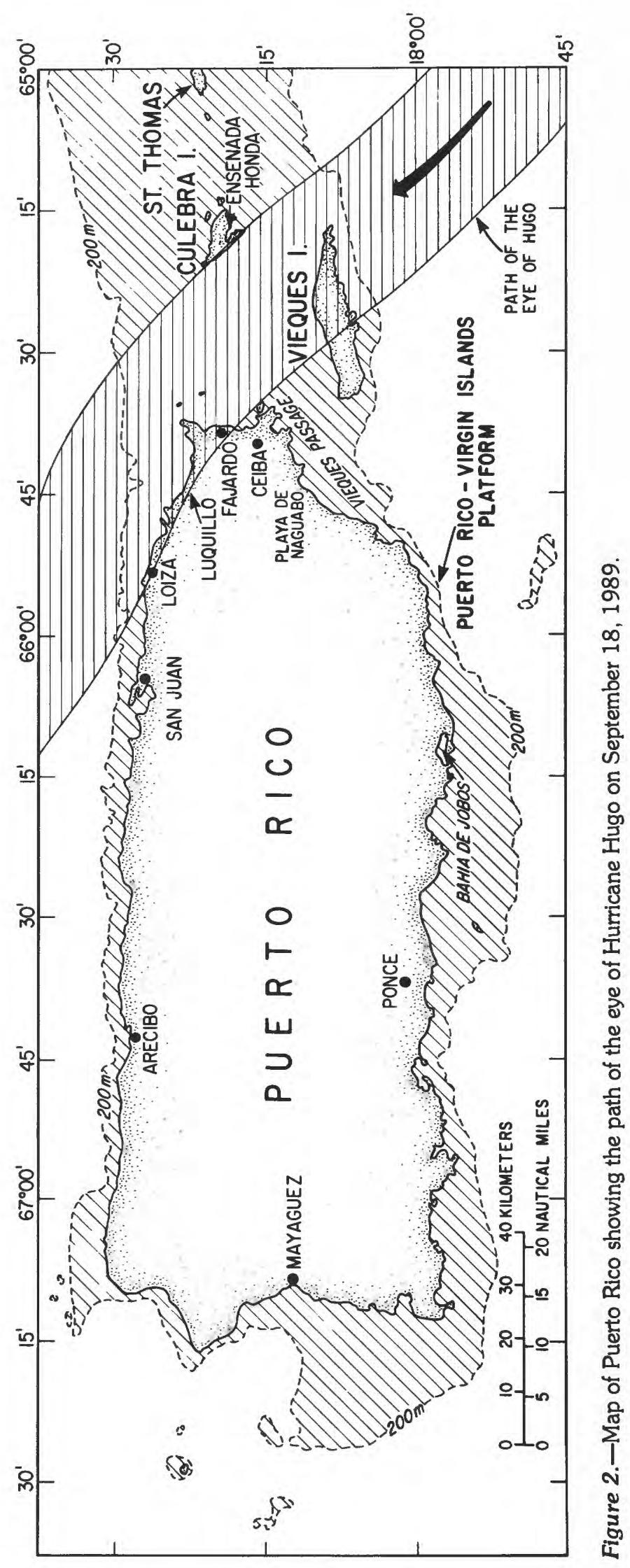




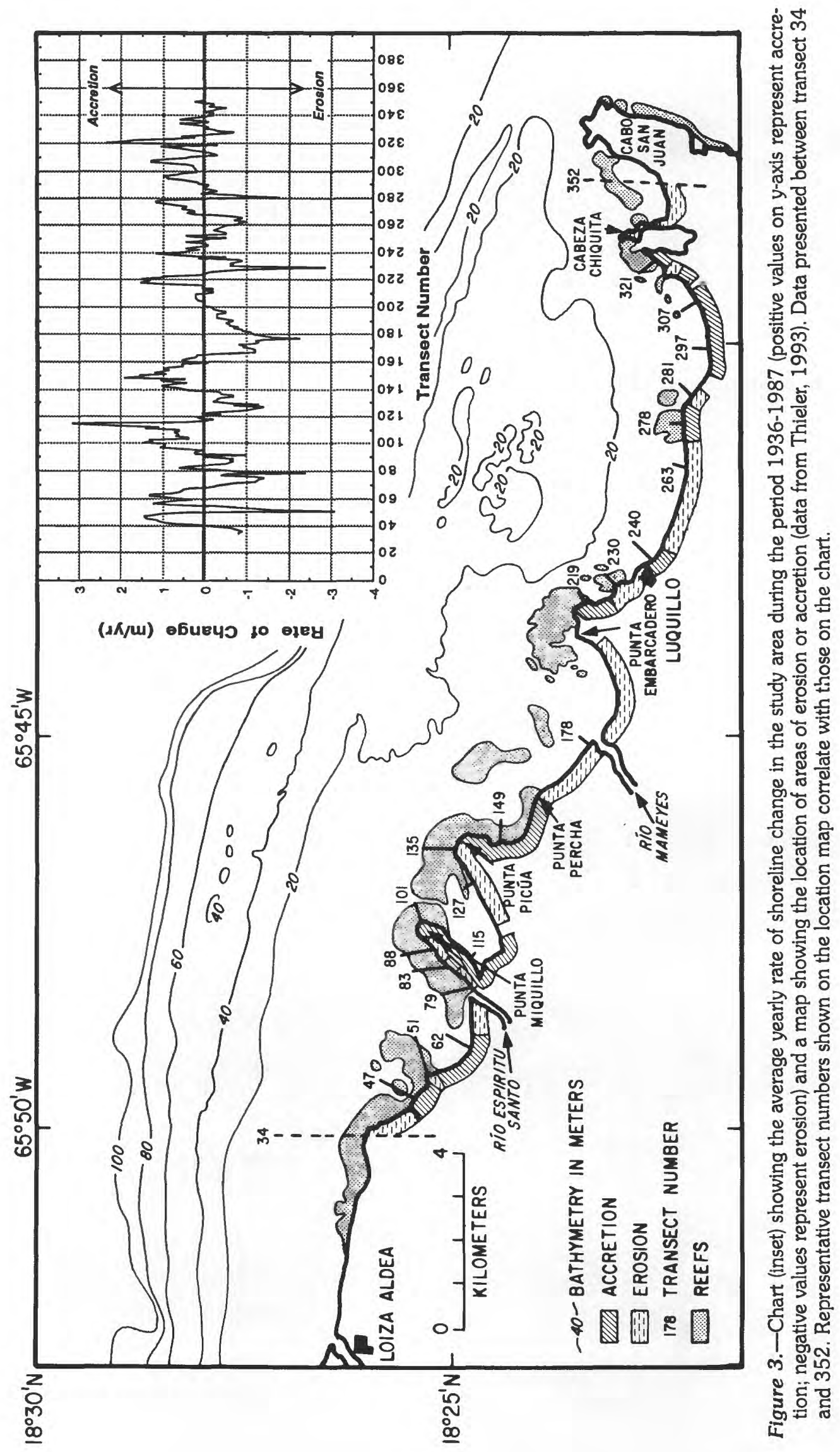




\section{METHODS}

The application of high-resolution sidescan-sonar techniques to sea-floor mapping is essential to adequately determine the complex spatial variability of the bottom morphology and sediment texture. Therefore, marine geologic surveys were conducted in April and May 1991 aboard the research vessel Jean A using a sidescan-sonar system, seismic-reflection profiling systems, and a surface grab sampler. These acoustic data are archived at the U.S. Geological Survey (USGS), Branch of Atlantic Marine Geology, Woods Hole, Mass. Additional bottom samples were collected in June 1992 using the research vessel Boriken.

The sidescan-sonar survey over the Luquillo insular shelf was conducted using a Klein $100-\mathrm{kHz}$ sidescan-sonar system; total swath width per trackline was $200 \mathrm{~m}$, and tracklines were selected to provide continuous sidescan-sonar coverage of the sea floor. The sidescan data were logged digitally at a sampling rate that resulted in a $0.1-\mathrm{m}$ pixel size in the across-track direction following the methodology outlined in Danforth and others (1991). A median filtering routine (Malinverno and others, 1990) was applied to the sidescan data to remove speckle noise, resulting in a $0.4-\mathrm{m}$ pixel size. The data were then further processed and mosaicked using procedures described by Danforth and others (1991). This mosaic was then used as a base map for the subsequent sampling phase of the investigation. Additional digital processing and mosaicking of a segment of the sidescan-sonar imagery (location shown in fig. 1) was conducted for quantitative analysis using routines developed by Chavez (1986) as modified by Paskevich (1992) for application to high-frequency sidescansonar imagery.

Concurrent with the acquisition of the sidescan-sonar imagery, approximately $650 \mathrm{~km}$ of $3.5-\mathrm{kHz}$ and Huntec Sea Otter seismic-reflection profiles were collected. These data were recorded using an analog EPC recorder. Bathymetry and sediment thickness of Holocene-age sediment were determined from these seismic-reflection data.

Bottom sediment samples were obtained using a Shipek grab sampler for the 1991 field work and a Van Veen sampler in 1992. Grain size analysis of the samples was conducted using a combination of wet sieve and Coulter counter techniques following the methodology of Poppe and others (1985). Analyses of calcium carbonate content were performed at the Puerto Rico Department of Natural Resources sedimentological laboratories using methods described by Carver (1971).

Ship navigation was conducted using a shore-base Miniranger Falcon IV transponder navigation system for the 1991 investigation and a Global Positioning System (GPS) satellite navigation system in 1992. Using these navigation data, the seismic-reflection profiles and 1991 bottom sample locations are accurate to within $\pm 5 \mathrm{~m}$. The sidescan towfish, however, was not navigated independently of the ship, thus, an additional maximum error from $15 \mathrm{~m}$ in shallow water to approximately $100 \mathrm{~m}$ in deeper areas exists in the sidescan imagery. Navigation on the 1992 sampling cruise aboard the RV Boriken had an accuracy of \pm $100 \mathrm{~m}$.

\section{MAPPING RESULTS}

Maps have been completed in a $105-\mathrm{km}^{2}$ area of the Luquillo insular shelf (fig. 1). These maps show sidescan-sonar imagery with ship tracklines (Maps A, B, and C (sheet 1)), bathymetry and bottom sample locations (Maps D, E, and F (sheet 2)), Holocene sediment thickness (Maps G, H, and I (sheet 3)), and a Pleis- tocene structural horizon (Maps $\mathrm{J}, \mathrm{K}$, and L (sheet 4)). On these sidescan images, areas of high acoustic backscatter intensity are black, and areas of low backscatter are white.

The sea floor in the study area is dominated by a series of eolianite ridges which are clearly expressed on the sidescan imagery as areas of high acoustic backscatter intensity with a high degree of backscatter variance (fig. 4; Maps J, K, and L). These ridges trend roughly east-west across the study area. Although samples of these rock ridges were not collected for verification, they are thought to be eolianite formed during Pleistocene time (Kaye, 1959). Similar eolianite dunes are common along the northern coast of Puerto Rico and crop out to the east on islands northeast of Cabo San Juan. Using seismic-reflection profiles, the Pleistocene surface, which is correlative with the surface of the eolianite ridges, can be traced as a strong reflector under the Holocene sediments (fig. 5) which, in turn, fill in depressions on the surface.

The surficial sediment can be subdivided into four acoustic facies (fig. 4) based on relative degree of acoustic backscatter shown on the sidescan-sonar images and sediment texture (fig. 6). These are: 1) low-backscatter sand-relatively fine-grained sand found in the nearshore region in areas of relatively low backscatter; 2) high-backscatter sand-relatively coarse-grained reefal-derived sands and gravelly sands found in areas of relatively high acoustic backscatter; 3) low-backscatter silt-silt to sandy silt found in areas of low backscatter on the outer shelf; and 4) intermediate-backscatter sandy silt-sandy silt to silty sand found in an area of relatively moderate-to-high backscatter along the shelfbreak. Textural data from samples are presented in Table 1.

The sand-size fraction of the sediment samples were analyzed for their skeletal carbonate (coralline algae, Halimeda, Echinodermata, coral fragments, Porifera, Molluska, Gorgonia, Annelida, Bryozoa, and Foraminifera), non-skeletal carbonate (ooid, aggregate, and peloid), and terrigenous (quartz, feldspar, and rock fragment) components. The average compositions of the sand is presented on figure 7, where they are subdivided into samples collected from the nearby beaches, those from the lowbackscatter sand facies collected from the inner shelf, those from the low-backscatter sand facies in close proximity to the eolianite (low backscatter "reefal" sands), those from the high-backscatter sand facies, and those from the low-backscatter silt facies.

The increase of the coral fragment component in samples from the beachface and from areas in close proximity to the eolianite in comparison to that of the low-backscatter inner-shelf sand is probably due to the proximity of the sediment to coral reefs that fringe the coast and to corals that are growing on the eolianite (fig. 4). However, the compositional (fig. 7) and textural (fig. 6) similarities of the low-backscatter sand from the beach to the eolianite suggests that they are the same deposit.

The average composition of the high-backscatter sand acoustic facies (fig. 7) is also similar to the composition of low-backscatter sand facies with an expected increase in the Halimeda component, which grows on the eolianite, and an unexplained minor reduction in the Echinodermata and Porifera components. However, the high-backscatter sand facies is coarser grained than the low-backscatter sand facies (fig. 4). Chemical analyses of the low- and high-backscatter sand facies show that the samples are greater than 85 percent calcium carbonate with all but two samples greater than 93 percent (fig. 8). This indicates that there is little input of terrigenous sediment into this area from the local rivers and that most of the sandy sediment is locally (biologically) derived from carbonate-producing organisms which grow on the local hardgrounds. Terrigenous deposition in the study area appears to be concentrated in the low-backscatter silt found on 


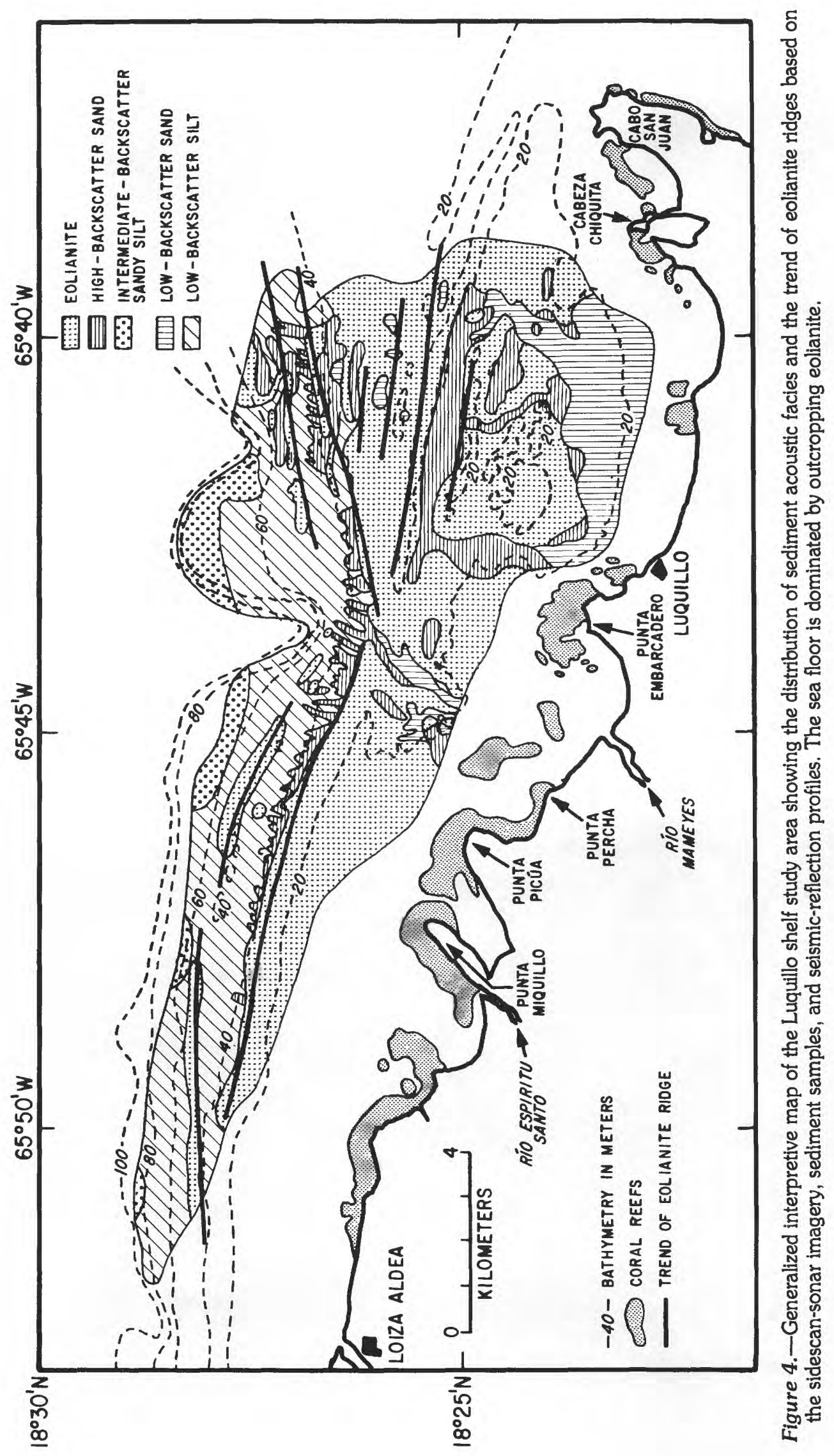




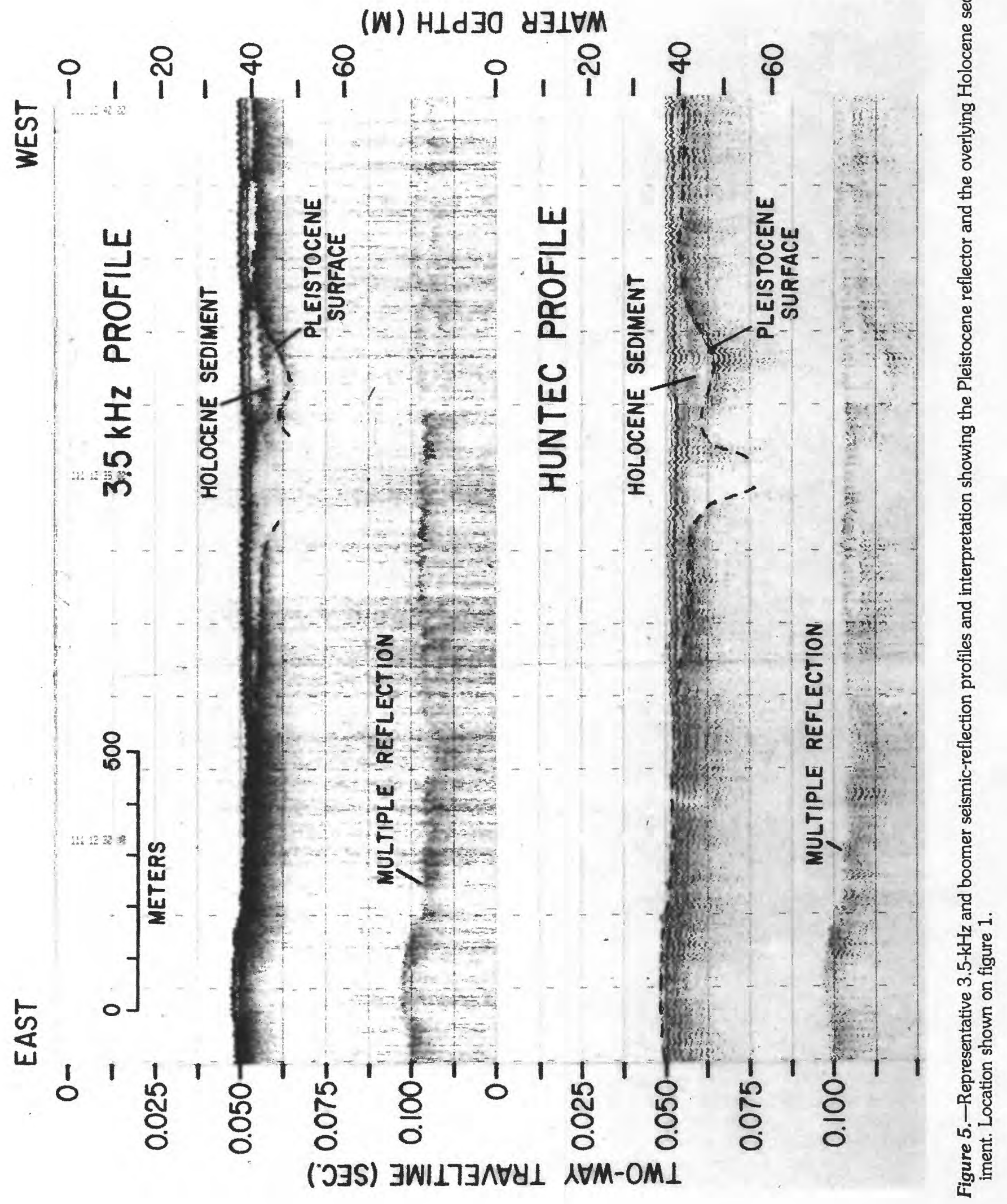




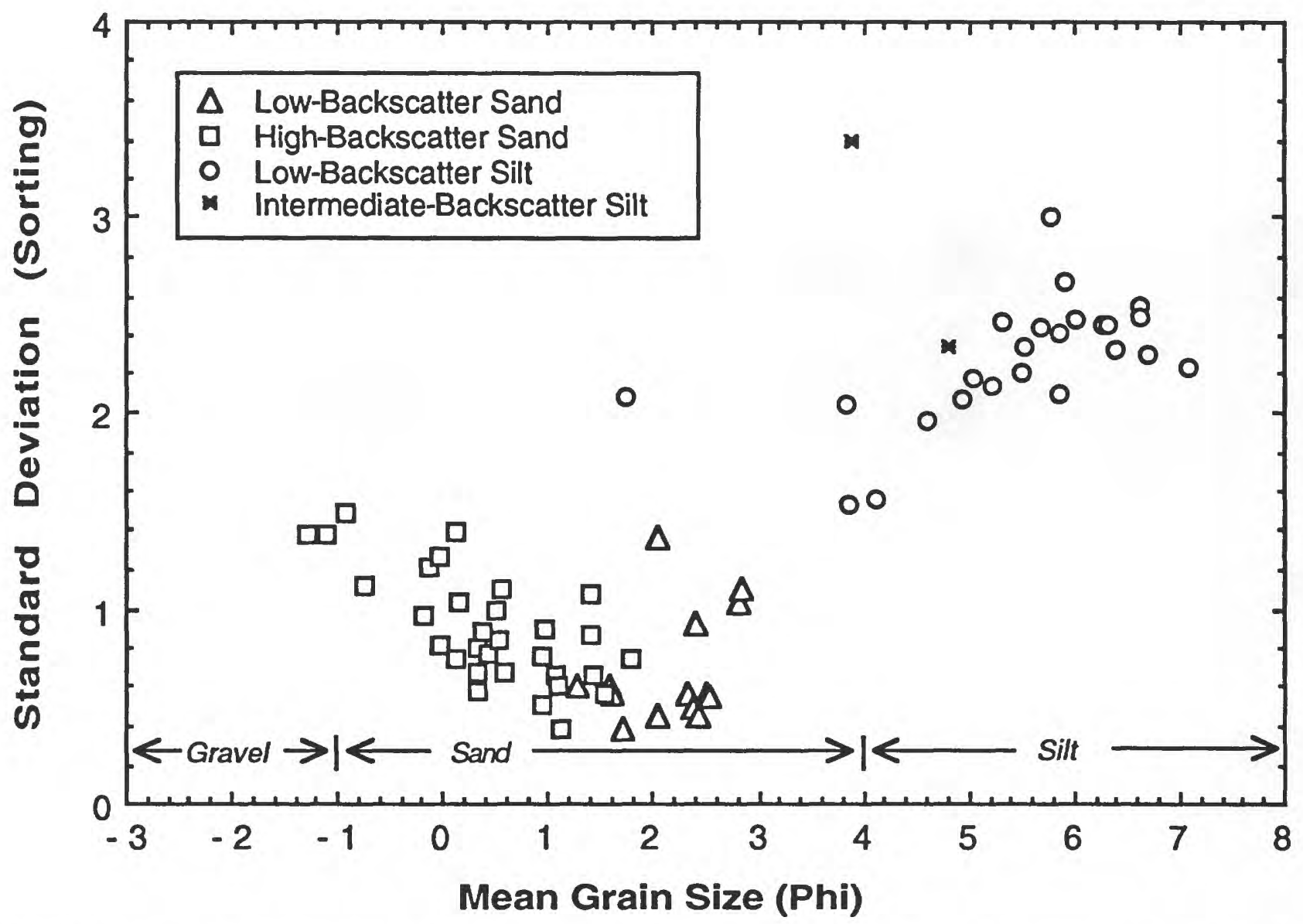

Figure 6. Relation between mean grain size (in phi-units) and standard deviation (sorting) of the sediment distribution for the four major acoustic facies shown on figure 4.

the outer insular shelf and is expressed by the relative increase of the terrigenous component of the sand-fraction (fig. 7) and calcium carbonate contents less than 71 percent (fig. 8).

\section{ANALYSIS OF SIDESCAN-SONAR IMAGERY}

The similarity of the composition of the low-backscatter sand and high-backscatter sand acoustic facies strongly suggests that the relative backscatter intensity displayed on the sidescan-sonar imagery is a function of sediment texture (fig. 6). Sidescan-sonar imagery is a graphical representation of how sound interacts with the sea floor. Relative backscatter intensity is a function of a variety of factors including sea-floor bathymetry, sea-floor roughness, the acoustic impedance contrast between the water and the sea floor, the frequency of the sonar used, and the angle of incidence of the sound wave front (Urick, 1983). However, there have been few studies designed to evaluate the relative importance of these factors (e.g., Mayer and others, 1993). Geophysical and sedimentologic data were analyzed over part of the imagery collected over the Luquillo insular shelf (fig. 1) in order to quantitatively test the relation between relative backscatter intensity and sediment texture (Gowen and others, 1993). A portion of the sidescansonar data was selected to create a composite digital mosaic (fig. 9). This area was chosen because of its manageable size (13 $\mathrm{km}^{2}$ ), because it contained a broad range of backscatter intensities which were representative of the entire survey area, and because sediment samples were located in many different backscatter regimes. On this digital mosaic, areas of high acoustic backscatter intensity are white, and areas of low backscatter are black, opposite to the display of relative backscatter intensity on Maps A through L (see sheets 1 through 4).

Statistical parameters of the digital mosaic were collected in $5 \times 5-\mathrm{m}$ areas, centered around each sediment sample location. This 5-m digital "sample size" was chosen due to the navigational accuracy of the sediment sample locations $( \pm 5 \mathrm{~m})$. The statistical parameters of digital number (DN) values in varied acoustic backscatter regimes were analytically compared with a suite of textural, compositional, and geochemical properties of the associated sediment samples (Gowen and others, 1993). The statistical parameters of the sidescan-sonar data used in the analyses were: the mean, standard deviation, and skewness of the DN values in the sampled area. The sedimentologic variables used in the analyses were: the mean, median, standard deviation (sorting), skewness, and kurtosis of the sediment grain-size distribution; mathematical combinations of the above; cumulative percentiles of single phi-units; percent gravel, sand, silt, and clay; percent calcium carbonate content; and percent coralline algae, Halimeda, Echinodermata, coral fragments, Porifera, Molluska, Gorgonia, Annelida, Bryozoa, Foraminifera, unknown skeletal fragments, ooids, aggregates, peloids, quartz, feldspar, rock fragments, and unknown terrigenous fragments. Variables not used in the analysis included the following: 
Beach Sand

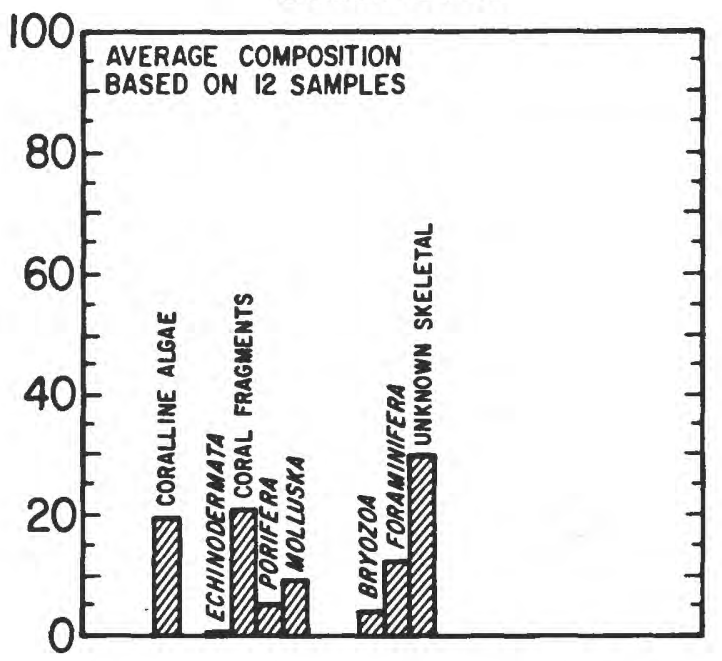

Low-Backscatter Inner-Shelf Sand

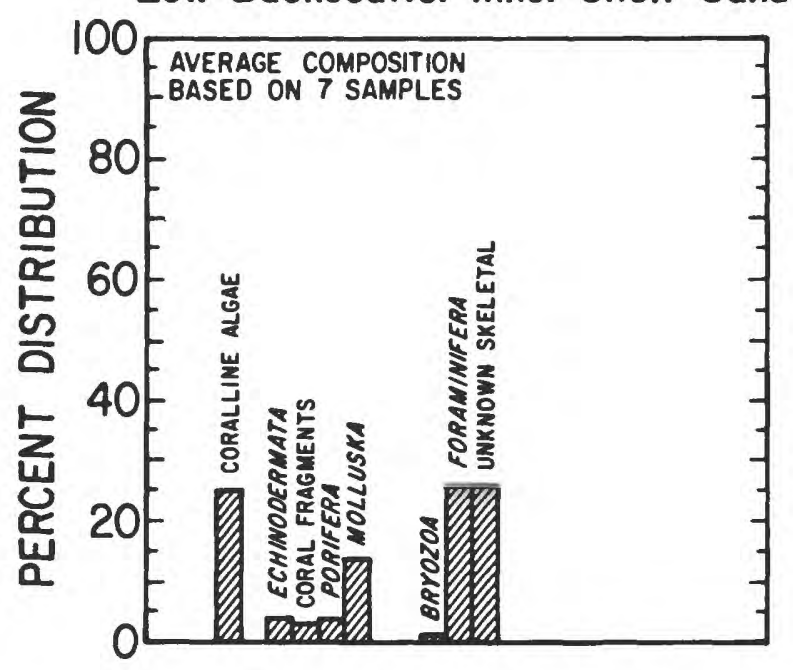

Low-Backscatter Reefal Sands

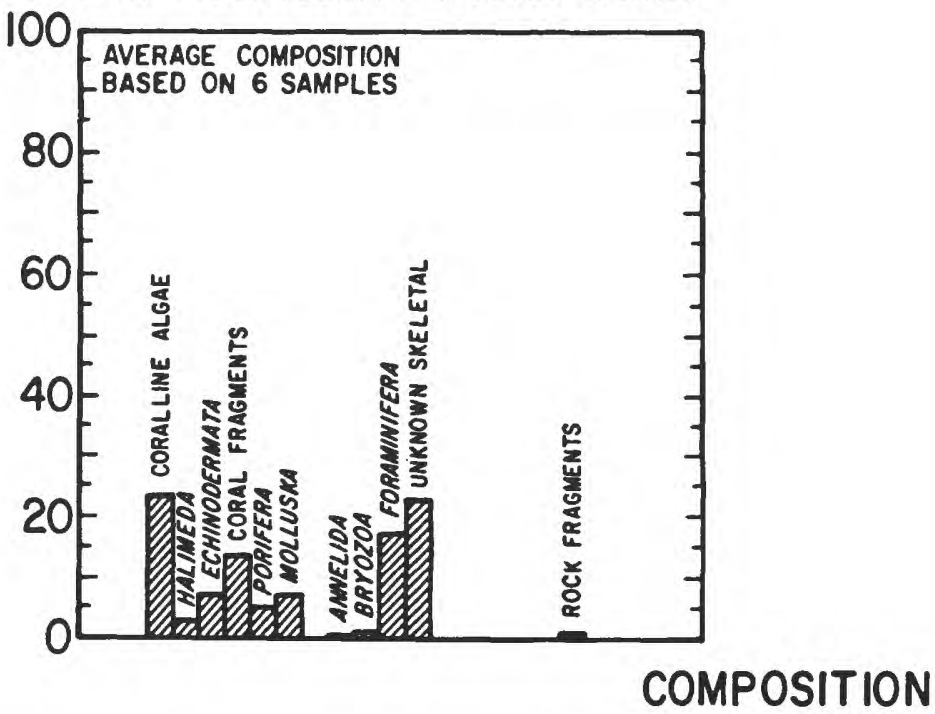

High-Backscatter Sand

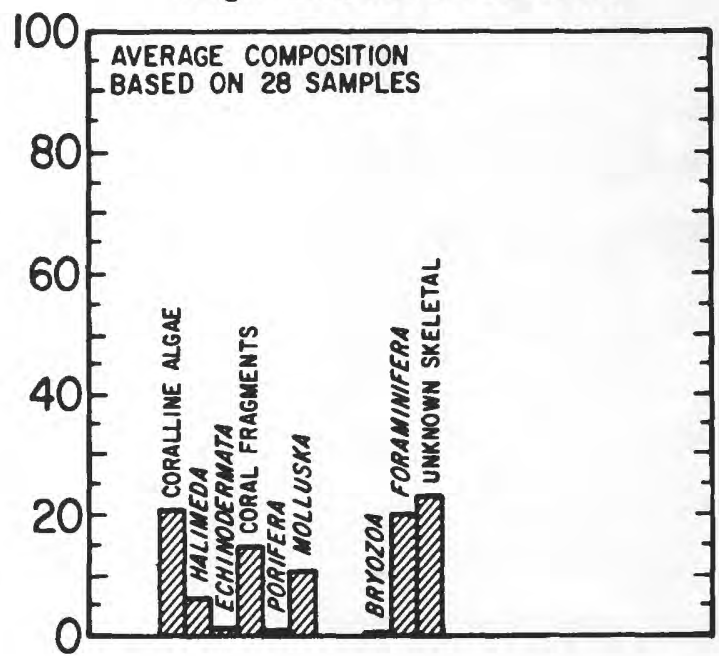

Low-Backscatter Silt

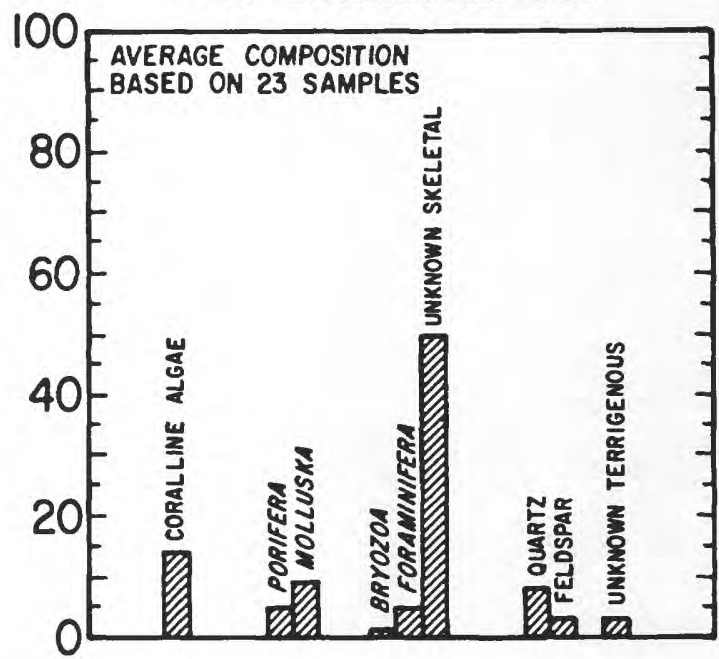


Table 1.-Sediment textural data. Sample numbers preceded by "B" indicate samples collected on the beachface; numbers preceded by "Bor" indicate samples collected in 1992 aboard the RV Boriken (see fig. 9 for sample locations); numbers preceded by "GS" indicate samples collected in 1991 aboard the RV Jean A (see Maps D, E, and F for sample locations); and numbers followed by "A" or "B" indicate duplicate analyses.

\begin{tabular}{|c|c|c|c|c|c|c|c|c|c|}
\hline Sample No. & $\begin{array}{c}\text { Gravel } \\
(\%)\end{array}$ & $\begin{array}{c}\text { Sand } \\
(\%)\end{array}$ & $\begin{array}{l}\text { Silt } \\
(\%)\end{array}$ & $\begin{array}{c}\text { Clay } \\
(\%)\end{array}$ & $\begin{array}{l}\text { Mean } \\
\text { (Phi) }\end{array}$ & $\begin{array}{l}\text { Median } \\
\text { (Phi) }\end{array}$ & $\begin{array}{l}\text { Standard } \\
\text { deviation }\end{array}$ & Skewness & Kurtosis \\
\hline B201 & 0.15 & 98.45 & 0.48 & 0.92 & 2.36 & 2.42 & 1.12 & 1.05 & 15.63 \\
\hline $\mathrm{B} 202$ & 11.08 & 87.00 & 0.55 & 1.37 & 2.08 & 2.49 & 1.91 & -0.19 & 3.11 \\
\hline $\mathrm{B} 203$ & 16.95 & 81.67 & 0.36 & 1.01 & 1.56 & 2.28 & 2.20 & -0.27 & 1.27 \\
\hline B204 & 0.46 & 97.83 & 0.57 & 1.14 & 2.13 & 2.28 & 1.34 & 0.74 & 8.85 \\
\hline B205 & 0.02 & 96.97 & 1.55 & 1.46 & 2.86 & 2.76 & 1.08 & 1.69 & 19.89 \\
\hline B206 & 0.03 & 99.97 & 0.00 & 0.00 & 2.08 & 2.22 & 0.64 & -0.58 & 1.11 \\
\hline B207 & 0.00 & 100.00 & 0.00 & 0.00 & 2.33 & 2.41 & 0.52 & -0.76 & 4.26 \\
\hline $\mathrm{B} 208$ & 2.18 & 97.03 & 0.23 & 0.56 & 1.64 & 1.76 & 1.25 & 0.11 & 11.71 \\
\hline B209 & 0.43 & 98.22 & 0.49 & 0.85 & 2.13 & 2.20 & 1.03 & 1.44 & 21.54 \\
\hline $\mathrm{B} 61$ & 0.00 & 100.00 & 0.00 & 0.00 & 1.70 & 1.69 & 0.45 & -0.02 & 5.29 \\
\hline B62 & 0.00 & 99.99 & 0.01 & 0.00 & 1.64 & 1.69 & 0.56 & -0.17 & 2.59 \\
\hline $\mathrm{B} 63$ & 0.00 & 99.91 & 0.09 & 0.00 & 2.31 & 2.36 & 0.62 & -0.58 & 3.80 \\
\hline Bor-02 & 0.94 & 97.95 & 0.36 & 0.75 & 1.26 & 1.28 & 1.08 & 1.71 & 25.55 \\
\hline Bor-05 & 4.03 & 93.86 & 0.92 & 1.19 & 1.02 & 0.98 & 1.46 & 1.09 & 14.51 \\
\hline Bor-07 & 7.30 & 90.05 & 1.35 & 1.30 & 0.74 & 0.70 & 1.54 & 1.30 & 13.80 \\
\hline Bor-08 & 1.88 & 99.12 & 0.00 & 0.00 & 0.88 & 0.98 & 0.81 & -0.27 & 0.58 \\
\hline Bor-09 & 5.45 & 91.94 & 0.82 & 1.78 & 0.90 & 0.82 & 1.57 & 1.52 & 15.69 \\
\hline Bor-10 & 12.97 & 84.10 & 1.24 & 1.69 & 0.75 & 0.86 & 1.91 & 0.63 & 6.82 \\
\hline Bor-11 & 0.02 & 14.36 & 78.96 & 6.67 & 5.10 & 4.91 & 1.45 & 0.85 & 4.60 \\
\hline Bor-12 & 1.89 & 96.55 & 0.68 & 0.88 & 0.73 & 0.61 & 1.22 & 1.91 & 24.82 \\
\hline Bor-13 & 7.17 & 91.02 & 0.56 & 1.25 & 0.34 & 0.27 & 1.41 & 1.87 & 22.33 \\
\hline Bor-14 & 2.72 & 95.87 & 0.31 & 1.10 & 0.93 & 0.88 & 1.27 & 1.72 & 23.16 \\
\hline Bor-15 & 28.50 & 70.51 & 0.19 & 0.80 & -0.36 & -0.39 & 1.48 & 1.19 & 14.97 \\
\hline Bor-17 & 5.12 & 93.6 & 0.45 & 0.83 & 0.33 & 0.32 & 1.16 & 2.28 & 34.06 \\
\hline Bor-19 & 3.49 & 94.79 & 0.63 & 1.09 & 0.47 & 0.41 & 1.24 & 2.34 & 31.88 \\
\hline Bor-20 & 9.70 & 87.89 & 0.79 & 1.62 & 0.51 & 0.41 & 1.62 & 1.52 & 15.35 \\
\hline Bor-24 & 38.60 & 59.61 & 0.50 & 1.28 & -0.51 & -0.63 & 1.65 & 1.58 & 16.75 \\
\hline Bor-30 & 53.62 & 45.13 & 0.30 & 0.95 & -0.96 & -1.13 & 1.59 & 1.52 & 17.14 \\
\hline Bor-34 & 1.95 & 96.22 & 0.58 & 1.25 & 0.69 & 0.55 & 1.26 & 2.35 & 30.00 \\
\hline Bor-35 & 23.26 & 75.19 & 0.48 & 1.06 & -0.15 & -0.25 & 1.49 & 1.65 & 19.48 \\
\hline Bor-37 & 0.00 & 74.81 & 21.89 & 3.31 & 3.62 & 3.36 & 1.49 & 1.14 & 6.82 \\
\hline Bor-38 & 0.12 & 98.30 & 0.94 & 0.65 & 1.23 & 1.16 & 1.00 & 2.34 & 33.53 \\
\hline Bor-43 & 2.02 & 95.68 & 1.60 & 0.69 & 0.87 & 0.68 & 1.30 & 1.35 & 14.46 \\
\hline Bor-44 & 0.47 & 97.16 & 1.69 & 0.69 & 1.05 & 0.87 & 1.15 & 1.84 & 22.22 \\
\hline Bor-45 & 1.01 & 96.95 & 0.55 & 1.49 & 0.86 & 0.67 & 1.34 & 2.27 & 26.87 \\
\hline Bor-46 & 1.20 & 96.16 & 1.33 & 1.31 & 0.93 & 0.75 & 1.35 & 2.00 & 22.15 \\
\hline Bor-47 & 10.25 & 88.72 & 0.28 & 0.75 & 0.15 & 0.16 & 1.19 & 1.88 & 28.05 \\
\hline Bor-53 & 0.02 & 96.92 & 1.83 & 1.24 & 2.66 & 2.56 & 1.05 & 1.79 & 21.58 \\
\hline Bor-54 & 0.06 & 98.10 & 0.75 & 1.09 & 1.85 & 1.71 & 1.12 & 1.83 & 22.67 \\
\hline Bor-55 & 0.01 & 78.04 & 21.09 & 0.86 & 3.41 & 3.35 & 1.12 & 0.81 & 7.69 \\
\hline Bor-56 & 0.00 & 97.41 & 1.56 & 1.03 & 2.21 & 2.10 & 1.10 & 1.71 & 20.23 \\
\hline Bor-58 & 0.09 & 65.68 & 29.63 & 4.59 & 3.96 & 3.65 & 1.57 & 1.03 & 5.65 \\
\hline Bor-59 & 7.21 & 91.54 & 0.43 & 0.82 & 0.80 & 0.91 & 1.37 & 0.93 & 13.22 \\
\hline Bor-60 & 1.35 & 97.24 & 0.47 & 0.94 & 1.09 & 1.10 & 1.19 & 1.61 & 21.00 \\
\hline Bor-61 & 1.70 & 96.40 & 0.86 & 1.04 & 1.13 & 1.12 & 1.29 & 1.56 & 19.03 \\
\hline Bor-66 & 0.23 & 97.29 & 1.58 & 0.90 & 2.76 & 2.65 & 0.91 & 1.86 & 27.94 \\
\hline Bor-67 & 0.00 & 88.96 & 4.67 & 6.37 & 3.46 & 3.01 & 1.77 & 1.22 & 5.38 \\
\hline Bor-68 & 0.00 & 83.78 & 12.62 & 3.60 & 3.53 & 3.19 & 1.51 & 1.26 & 6.85 \\
\hline Bor-75 & 11.43 & 70.83 & 12.56 & 5.18 & 2.01 & 1.78 & 2.88 & 0.27 & 0.91 \\
\hline Bor-80 & 0.52 & 69.61 & 26.36 & 3.50 & 3.94 & 3.67 & 1.43 & 0.79 & 9.71 \\
\hline Bor-test1 & 0.48 & 98.04 & 0.73 & 0.75 & 2.38 & 2.40 & 1.01 & 1.24 & 20.01 \\
\hline GS01 & 0.00 & 10.93 & 57.54 & 31.53 & 6.38 & 5.59 & 2.33 & 0.19 & -1.16 \\
\hline GSO2 & 0.26 & 9.28 & 55.91 & 34.55 & 6.70 & 6.16 & 2.30 & 0.02 & -0.76 \\
\hline GSO3 & 45.67 & 53.96 & 0.37 & 0.00 & -0.96 & -0.87 & 1.28 & -0.23 & 3.45 \\
\hline GSO4 & 0.06 & 18.68 & 42.97 & 38.29 & 6.61 & 5.99 & 2.55 & 0.03 & -1.31 \\
\hline GSO5 & 0.12 & 28.06 & 56.62 & 15.19 & 5.20 & 4.65 & 2.14 & 0.52 & 0.64 \\
\hline GS06 & 0.16 & 20.68 & 60.42 & 18.74 & 5.50 & 4.78 & 2.21 & 0.46 & 0.15 \\
\hline GS07 & 0.02 & 24.01 & 48.93 & 27.04 & 6.01 & 5.27 & 2.48 & 0.27 & -0.93 \\
\hline GS08A & 17.51 & 81.35 & 1.14 & 0.00 & 0.19 & 0.15 & 1.36 & 0.44 & 3.50 \\
\hline GS08B & 29.56 & 69.29 & 1.15 & 0.00 & -0.30 & -0.37 & 1.30 & 0.71 & 4.18 \\
\hline GSO9 & 0.02 & 16.48 & 46.69 & 36.81 & 6.63 & 5.96 & 2.50 & 0.06 & -1.24 \\
\hline GS10 & 0.20 & 20.39 & 48.86 & 30.55 & 6.16 & 5.31 & 2.57 & 0.18 & -0.97 \\
\hline GS11 & 0.20 & 20.68 & 45.83 & 33.29 & 6.31 & 5.63 & 2.54 & 0.09 & -1.01 \\
\hline
\end{tabular}


Table 1.-Continued

\begin{tabular}{|c|c|c|c|c|c|c|c|c|c|}
\hline Sample No. & $\begin{array}{c}\text { Gravel } \\
(\%)\end{array}$ & $\begin{array}{c}\text { Sand } \\
(\%)\end{array}$ & $\begin{array}{l}\text { Silt } \\
(\%)\end{array}$ & $\begin{array}{l}\text { Clay } \\
(\%)\end{array}$ & $\begin{array}{c}\text { Mean } \\
\text { (Phi) }\end{array}$ & $\begin{array}{l}\text { Median } \\
\text { (Phi) }\end{array}$ & $\begin{array}{l}\text { Standard } \\
\text { deviation }\end{array}$ & Skewness & Kurtosis \\
\hline GS12 & 0.07 & 13.98 & 66.75 & 19.2 & 5.84 & 5.35 & 2.10 & 0.27 & -0.13 \\
\hline GS13 & 0.22 & 31.15 & 39.80 & 28.84 & 5.90 & 5.29 & 2.68 & 0.13 & -0.93 \\
\hline GS14 & 0.36 & 36.02 & 44.24 & 19.38 & 5.31 & .4 .63 & 2.47 & 0.38 & -0.19 \\
\hline GS15 & 40.23 & 59.52 & 0.25 & 0.00 & -0.73 & -0.69 & 1.06 & 0.24 & 3.58 \\
\hline GS16 & 0.10 & 35.85 & 51.28 & 12.77 & 4.94 & 4.44 & 2.07 & 0.61 & 1.22 \\
\hline GS17 & 0.19 & 29.38 & 56.96 & 13.46 & 5.04 & 4.58 & 2.18 & 0.48 & 1.06 \\
\hline GS18 & 3.74 & 96.14 & 0.12 & 0.00 & 1.41 & 1.70 & 1.04 & -1.25 & 5.20 \\
\hline GS19 & 0.15 & 99.78 & 0.07 & 0.00 & 1.50 & 1.66 & 0.71 & -0.50 & 3.72 \\
\hline GS20A & 0.16 & 99.62 & 0.22 & 0.00 & 1.08 & 1.07 & 0.64 & 0.14 & 4.52 \\
\hline GS20B & 0.16 & 99.52 & 0.31 & 0.00 & 1.11 & 1.13 & 0.69 & 0.05 & 4.36 \\
\hline GS21 & 0.00 & 5.31 & 53.84 & 40.85 & 7.09 & 6.8 & 2.24 & 0.02 & -1.31 \\
\hline GS22 & 0.08 & 16.84 & 52.27 & 30.81 & 6.27 & 5.63 & 2.45 & 0.11 & -0.92 \\
\hline GS23 & 5.71 & 45.38 & 33.13 & 15.78 & 3.88 & 3.82 & 3.39 & 0.17 & -0.89 \\
\hline GS24 & 1.45 & 23.54 & 63.15 & 11.85 & 4.81 & 4.66 & 2.34 & 0.09 & 1.04 \\
\hline GS25 & 0.24 & 22.37 & 52.57 & 24.82 & 5.86 & 5.26 & 2.42 & 0.20 & -0.57 \\
\hline GS26 & 0.00 & 30.39 & 45.29 & 24.32 & 5.66 & 4.82 & 2.44 & 0.32 & -0.79 \\
\hline GS27 & 50.25 & 49.58 & 0.17 & 0.00 & -0.94 & -1.01 & 1.39 & 0.47 & 2.82 \\
\hline GS28 & 0.00 & 17.19 & 51.69 & 31.12 & 6.30 & 5.55 & 2.46 & 0.18 & -1.10 \\
\hline GS29 & 12.18 & 87.75 & 0.07 & 0.00 & -0.02 & -0.04 & 0.84 & 0.19 & 3.37 \\
\hline GS30A & 1.26 & 98.66 & 0.08 & 0.00 & 0.94 & 0.97 & 0.81 & -0.29 & 3.46 \\
\hline GS30B & 1.47 & 98.37 & 0.16 & 0.00 & 0.97 & 0.97 & 0.79 & -0.22 & 3.83 \\
\hline GS31 & 38.07 & 61.93 & 0.00 & 0.00 & -0.41 & -0.06 & 1.19 & 0.26 & 2.28 \\
\hline GS32 & 1.23 & 98.74 & 0.03 & 0.00 & 1.24 & 1.30 & 0.74 & -0.98 & 6.43 \\
\hline GS33 & 0.25 & 97.94 & 1.81 & 0.00 & 2.54 & 2.62 & 0.67 & -0.92 & 6.61 \\
\hline GS34 & 0.10 & 99.75 & 0.15 & 0.00 & 2.47 & 2.57 & 0.72 & -1.63 & 7.41 \\
\hline GS35 & 9.74 & 90.26 & 0.00 & 0.00 & 0.62 & 0.81 & 1.14 & -0.67 & 3.32 \\
\hline GS36 & 1.28 & 95.24 & 3.47 & 0.00 & 2.45 & 2.79 & 1.19 & -1.38 & 4.48 \\
\hline GS37 & 4.80 & 95.14 & 0.06 & 0.00 & 0.45 & 0.54 & 0.84 & -0.28 & 4.02 \\
\hline GS38 & 0.29 & 99.71 & 0.00 & 0.00 & 0.91 & 0.89 & 0.57 & 0.18 & 5.09 \\
\hline GS40A & 0.77 & 99.16 & 0.07 & 0.00 & 1.29 & 1.39 & 0.84 & -0.39 & 2.98 \\
\hline GS40B & 1.55 & 98.45 & 0.00 & 0.00 & 1.13 & 1.20 & 0.94 & -0.36 & 2.61 \\
\hline GS45 & 27.99 & 72.00 & 0.01 & 0.00 & 1.74 & 2.68 & 2.08 & -0.40 & -1.24 \\
\hline GS46 & 0.21 & 27.47 & 52.60 & 19.73 & 5.52 & 4.88 & 2.34 & 0.34 & -0.20 \\
\hline GS47 & 9.25 & 90.75 & 0.00 & 0.00 & 0.19 & 0.32 & 0.89 & -0.45 & 4.71 \\
\hline GS48 & 49.10 & 50.90 & 0.00 & 0.00 & -1.16 & -0.97 & 1.26 & -0.31 & 2.29 \\
\hline GS49 & 1.30 & 98.47 & 0.23 & 0.00 & 1.51 & 1.61 & 0.75 & -1.08 & 7.45 \\
\hline GS50 & 2.82 & 97.18 & 0.00 & 0.00 & 0.32 & 0.34 & 0.68 & -0.26 & 4.12 \\
\hline GS51 & 6.13 & 93.87 & 0.00 & 0.00 & 0.34 & 0.45 & 0.78 & -0.64 & 3.99 \\
\hline GS52 & 10.64 & 89.36 & 0.00 & 0.00 & 0.5 & 0.71 & 1.13 & -0.94 & 4.03 \\
\hline GS53 & 2.18 & 97.82 & 0.00 & 0.00 & 1.00 & 1.03 & 0.80 & -1.05 & 6.19 \\
\hline GS54 & 5.16 & 94.84 & 0.00 & 0.00 & 0.55 & 0.59 & 0.90 & -0.13 & 3.57 \\
\hline GS55A & 4.03 & 95.87 & 0.09 & 0.00 & 0.71 & 0.77 & 0.88 & -0.32 & 3.47 \\
\hline GS55B & 0.25 & 99.49 & 0.26 & 0.00 & 1.54 & 1.66 & 0.87 & -0.34 & 3.28 \\
\hline GS56 & 1.89 & 97.97 & 0.13 & 0.00 & 0.95 & 0.91 & 0.90 & -0.15 & 3.39 \\
\hline GS57 & 0.24 & 98.09 & 1.67 & 0.00 & 1.82 & 1.92 & 0.87 & -0.46 & 4.43 \\
\hline GS58 & 0.00 & 99.00 & 1.00 & 0.00 & 2.32 & 2.41 & 0.72 & -1.31 & 7.09 \\
\hline GS59 & 0.09 & 99.57 & 0.34 & 0.00 & 2.00 & 2.07 & 0.60 & -0.80 & 5.73 \\
\hline GS60 & 1.38 & 89.61 & 9.02 & 0.00 & 2.05 & 2.11 & 1.28 & -0.23 & 2.74 \\
\hline GS64 & 20.38 & 79.29 & 0.33 & 0.00 & 0.18 & 0.35 & 1.31 & -0.09 & 2.72 \\
\hline GS65A & 1.22 & 98.78 & 0.00 & 0.00 & 1.01 & 1.03 & 0.77 & -0.40 & 3.52 \\
\hline GS65B & 0.59 & 99.41 & 0.00 & 0.00 & 0.93 & 0.95 & 0.70 & -0.33 & 2.98 \\
\hline GS66 & 0.03 & 65.15 & 28.15 & 6.67 & 3.84 & 3.50 & 2.04 & 0.64 & 2.08 \\
\hline GS67 & 0.16 & 48.17 & 42.13 & 9.55 & 4.61 & 4.07 & 1.96 & 0.67 & 1.90 \\
\hline GS69 & 0.34 & 61.18 & 34.01 & 4.46 & 4.11 & 3.77 & 1.56 & 0.67 & 4.27 \\
\hline GS70 & 0.19 & 67.17 & 29.09 & 3.55 & 3.85 & 3.65 & 1.53 & 0.78 & 5.96 \\
\hline GS73 & 0.47 & 99.53 & 0.00 & 0.00 & 1.64 & 1.81 & 0.65 & -1.28 & 6.12 \\
\hline GS74 & 7.75 & 92.14 & 0.12 & 0.00 & 0.37 & 0.52 & 0.90 & -0.55 & 4.13 \\
\hline GS75 & 14.14 & 85.86 & 0.00 & 0.00 & 0.19 & 0.38 & 1.05 & -0.56 & 3.00 \\
\hline GS76 & 20.01 & 79.99 & 0.00 & 0.00 & -0.27 & -0.28 & 0.97 & -0.37 & 2.91 \\
\hline GS79 & 5.60 & 94.40 & 0.00 & 0.00 & 0.55 & 0.66 & 0.83 & -0.90 & 4.96 \\
\hline GS81 & 0.25 & 99.75 & 0.00 & 0.00 & 1.06 & 1.02 & 0.46 & -0.16 & 5.5 \\
\hline GS83 & 0.03 & 87.78 & 12.19 & 0.00 & 2.69 & 2.64 & 0.98 & -0.22 & 2.59 \\
\hline GS84 & 0.00 & 78.91 & 21.09 & 0.00 & 2.83 & 2.83 & 1.09 & -0.48 & 2.67 \\
\hline GS85 & 0.07 & 99.59 & 0.34 & 0.00 & 2.35 & 2.43 & 0.62 & -0.98 & 5.69 \\
\hline GS87 & 6.03 & 93.86 & 0.11 & 0.00 & 0.94 & 0.98 & 0.94 & -0.76 & 4.36 \\
\hline GS89A & 11.03 & 88.92 & 0.05 & 0.00 & 0.26 & 0.36 & 1.07 & -0.44 & 4.07 \\
\hline GS89B & 5.25 & 94.70 & 0.06 & 0.00 & 0.51 & 0.54 & 0.91 & -0.04 & 3.79 \\
\hline
\end{tabular}




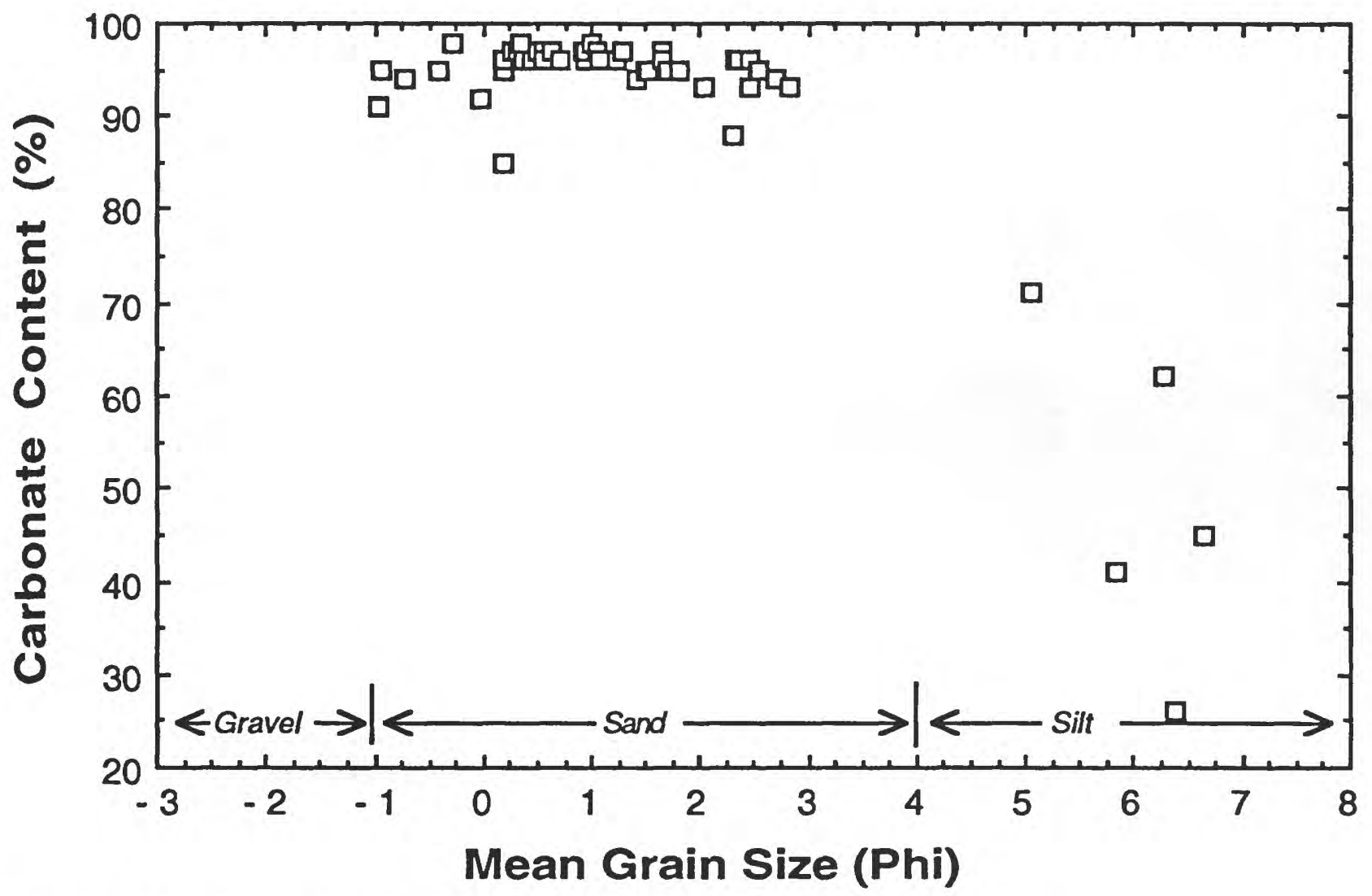

Figure 8. Relation between calcium carbonate concentration and mean grain size (in phi-units).

1. sea-floor topography because the data analyzed pertained to a relatively flat, sediment-covered sea floor;

2. sea-floor roughness due to a lack of data;

3. vehicle altitude (angle of incidence) because the towfish was towed approximately $13 \mathrm{~m}$ above the sea floor in this area of the survey with little variation; and

4. subbottom penetration because it was reasoned that the highfrequency signal would not penetrate the sea floor.

A comparative graphical analysis of all variables yielded poor correlations with the exception of the correlation between mean grain size and mean DN value for the $5 \times 5$-m sample (Gowen and others, 1993) (fig. 10). Note that the exponential relationship suggests that the DN values for finer grained sediments are less sensitive to changes in mean grain size than are those of coarser grained sediments.

To test this relationship, visual inspection of acoustic facies boundaries were conducted using scuba diving techniques (Gowen, 1993) and additional sediment samples were collected in 1992 (sample locations shown on figure 9) and analyzed using the same techniques as the 1991 data (Gowen and others, 1993). Despite potential changes in the sediment distribution over the preceding year, and the reduced navigational accuracy, these additional sedimentologic data reinforced the validity of the original correlation (Gowen and others, 1993): grain size is the dominant factor controlling relative backscatter intensity with the $100-\mathrm{kHz}$ sidescan-sonar system in the study area.

\section{DISCUSSION}

Compositional and textural data augmented with the sidescan imagery and sediment isopach maps (Maps $G, H$, and $I$ ) suggests that fine-grained sandy sediment derived from the local hardgrounds and any sediment removed from the shoreline resides on the inner shelf, generally inshore of the eolianite, forming the low-backscatter sand facies. Seismic-reflection profiles show that a sand deposit, in places up to $20 \mathrm{~m}$ thick (Map G), has formed landward of the eolianite and is a potential economic resource. In addition, a series of northeast-southwest-trending "channels" that cut across the eolianite (Maps $\mathrm{J}, \mathrm{K}$, and L), most likely subaerially formed, have been partially filled by the low-backscatter sand (fig. 5).

A series of elongate areas of high backscatter on the sidescan imagery seaward of the eolianite ridges are composed of the high-backscatter sand facies (figs. 4 and 9). The sediment composition and sidescan imagery (fig. 11) show that these coarsegrained sand and gravelly sand deposits were derived from the eolianite and transported in a general offshore direction. These high-backscatter "wisps" on the sidescan-sonar images are oriented northeast/southwest, roughly perpendicular to the shoreline (fig. 4). Although sediment cores are not available, continuous internal reflectors on subbottom profiles suggest that these high-backscatter sands form relatively thin deposits that floor elongate furrows in the surrounding low-backscatter silt facies. Similar features (termed rippled scour depressions) have 


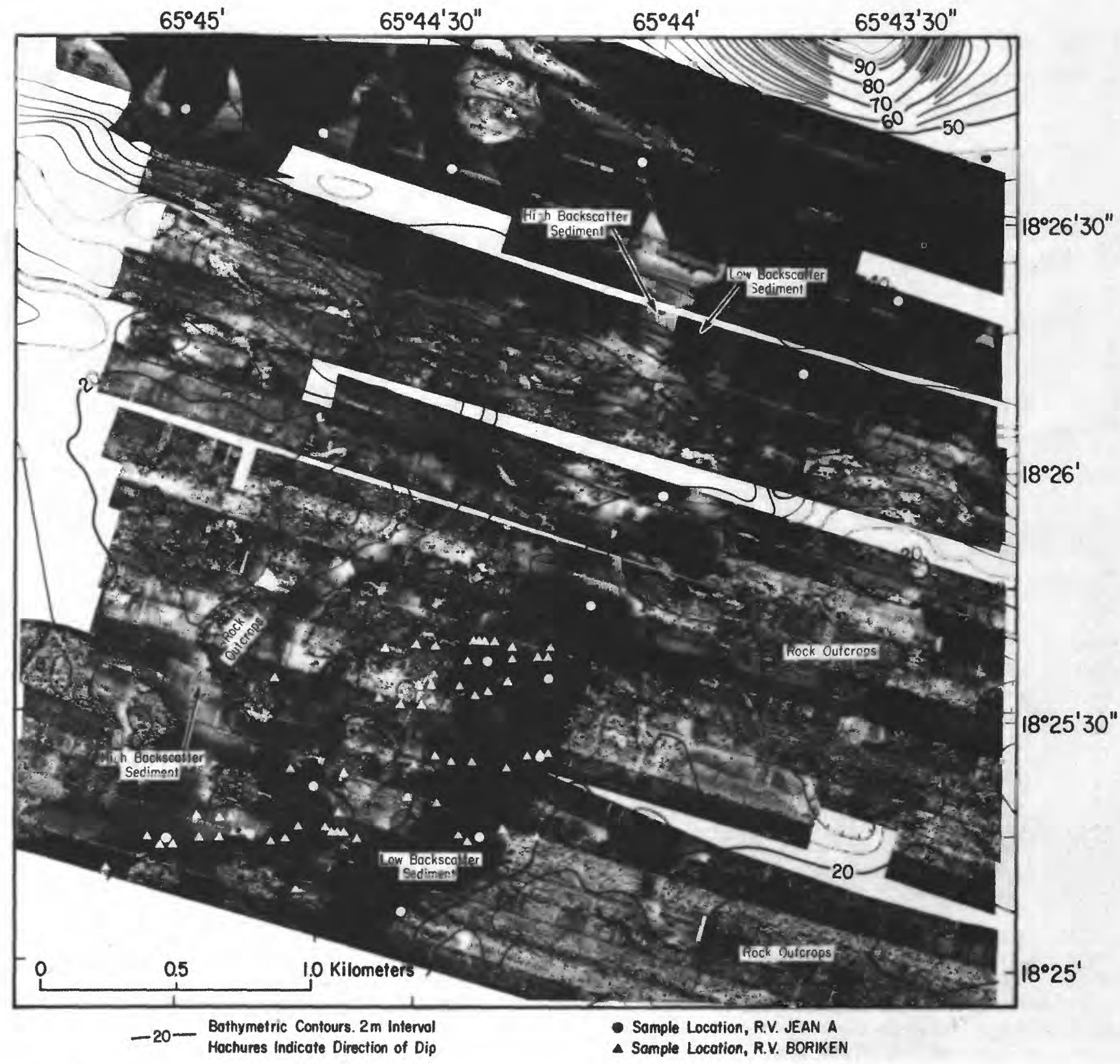

Figure 9.-Digital mosaic of a segment of the sidescan-sonar image shown on Map B (see fig. 1 for location). Also shown are bathymetric contours in meters and sediment sample locations. Areas of high backscatter are white and areas of low backscatter are black. Note the elongate areas of high backscatter seaward (north) of the eolianite, described as elongate rippled depressions (fig. 11). Figure modified from Gowen and others (1993).

been described in a variety of shelf and nearshore settings and are typically found in a shore-normal orientation (for example, Cacchione and others, 1984). How these furrows initially form is unknown, but studies suggest that coarse-grained sediment plays an important role in furrow initiation, as small furrows appear to form where rows of mobile coarser grained sediment have been aligned by bottom currents (Flood, 1981). The rippled scour depressions may then develop as a result of enhanced erosion created by the greater surface roughness, with localized abrasion or scour around particles on the bed (Allen, 1969). Both Cac- chione and others (1984) and Black and Healy (1988) suggest that bottom stresses due to waves are probably the major component contributing to the resuspension of bottom materials. However, Cacchione and others (1984) suggest the concurrent transporting action of a quasi-steady current (such as a current flowing generally seaward across the inner shelf during storminduced downwelling events) is a more likely cause for the elongate furrows, while Black and Healy (1988) suggest that the ripples and the furrows are formed as a direct result of bed mobilization by convergent waves. 


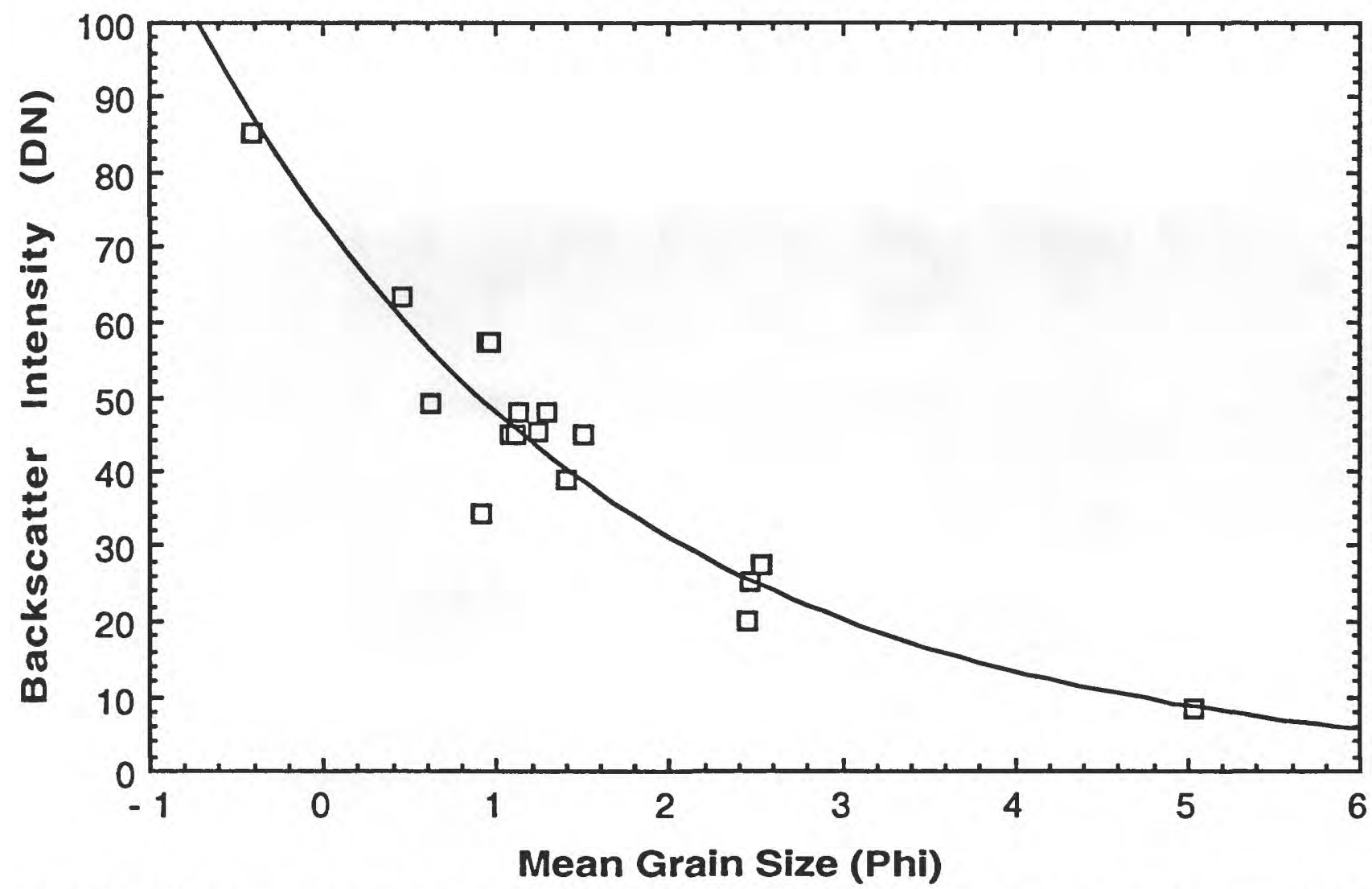

Figure 10. Relation between mean grain size (in phi-units) and mean DN value for the RV Jean A samples. Figure modified from Gowen and others (1993).

Although the oceanographic processes responsible for the offshore net sediment transport direction on the Luquillo insular shelf are unknown, the northeast/southwest orientation of the high-backscatter wisps seaward of the eolianite ridges (fig. 4) show that it is dominant throughout the study area. It is reasonable to infer that the enhanced bottom stresses produced by the intensified quasi-steady (downwelling current) and oscillatory flows (waves) are capable of resuspending and transporting coarse-grained sand from the eolianite seaward onto the lowbackscatter silt acoustic facies, while the inner shelf fine-grained sand is effectively trapped in the nearshore zone by the eolianite ridges.

\section{SUMMARY}

Applications of image analysis techniques used in this study include sea-floor mapping and resource evaluation. This methodology enables the creation of sediment-texture distribution maps which can be used to locate and evaluate natural resource potential. The spatial distribution of sedimentary facies can be mapped in much greater detail by combining sidescan-sonar data and conventional sampling. In addition, the strong correlation found between mean grain size and mean DN value (fig. 10) introduces the potential to false-color enhance the sidescan imagery in order to present the acoustic and grain-size data together in a single image (Gowen, 1993). These investigative and analytical techniques can be extremely useful to insular territories and nations which need to effectively utilize their offshore resources.

\section{ACKNOWLEDGMENTS}

The success of this program was based on the broad range of technical support provided by the USGS Puerto Rico Marine Geology Program and the Program for the Study of Developed Shorelines directed by Orrin H. Pilkey, Duke University. Navigation support of offshore surveys was provided by Barry Irwin and Juan Trias and shipboard support was provided by Milton Carlo. All illustrations were prepared by Jeff Zwinakis and Dann Blackwood. Helpful reviews of the maps and manuscript were provided by Bradford Butman, David Twichell, and Harley Knebel. In addition, we appreciate the cooperation of the captain and crew of the research vessel Jean A, provided by the Department of Natural Resources, Commonwealth of Puerto Rico. Funding for this program was initiated in 1989 by the Office of the thenU.S. Secretary of the Interior, Manuel Lujan. 


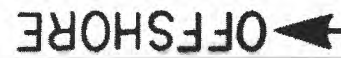

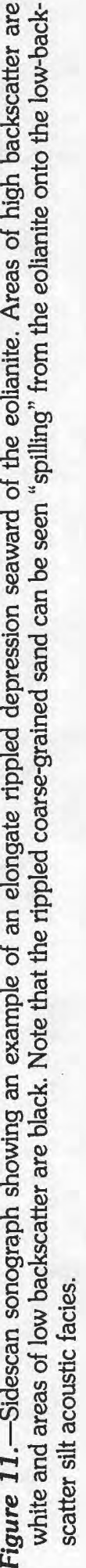




\section{REFERENCES CITED}

Allen, J.R.L., 1969, Erosional current marks of weakly cohesive mud beds: Journal of Sedimentary Petrology, v. 39, p. 607623.

Black, K.P., and Healy, T.R., 1988, Formation of ripple bands in a wave-convergence zone: Journal of Sedimentary Petrology, v. 58, p. 195-207.

Briggs, R.P., and Aguilar-Cortes, E., 1980, Geologic map of the Fajardo and Cayo Icacos quadrangles, Puerto Rico: U.S. Geological Survey Miscellaneous Investigations Series Map I1153 , scale 1:20,000, 1 sheet.

Cacchione, D.A., Drake, D.E., Grant, W.D., and Tate, G.B., 1984, Rippled scour depressions on the inner continental rise off central California: Journal of Sedimentary Petrology, v. 54 , p. $1280-1291$.

Carver, R.E., 1971, Procedures in sedimentary petrography: New York, John Wiley and Sons, Inc., 653 p.

Chavez, P.S., 1986, Processing techniques for digital sonar images from GLORIA: Photogrammetric Engineering and Remote Sensing, v. 52, p. 1133-1145.

Danforth, W.W., O'Brien, T.F., and Schwab, W.C., 1991, USGS image processing system: near real-time mosaicking of highresolution side scan SONAR data: Sea Technology, v. 32, p. 54-59.

Danforth, W.W., and Thieler, E.R., 1992a, Digital Shoreline Mapping System (DSMS) user's guide, version 1.0: U.S. Geological Survey Open-File Report 92-240, 33 p. 1992b, Digital Shoreline Analysis System (DSAS) user's guide, version 1.0: U.S. Geological Survey Open-File Report 92-355, $41 \mathrm{p}$.

Flood, R.D., 1981, Distribution, morphology, and origin of sedimentary furrows in cohesive sediments, Southampton water: Sedimentology, v. 28, p. 511-529.

Gowen, M.H., 1993, Analysis of high-resolution sidescan-sonar data: applications to sea-floor mapping and resource evaluation: Durham, N.C., Duke University, unpublished master's thesis, $163 \mathrm{p}$.

Gowen, M.H., Schwab, W.C., and Danforth, W.W., 1993, Analysis of high resolution sidescan-sonar: applications to sea floor mapping and resource evaluation: Proceedings of the Institute of Acoustics, Acoustic Classification and Mapping of the Seabed, v. 15, pt. 2, p. 311-318.

Grove, K.A., Pilkey, O.H., and Trumbull, J.V.A., 1982, Mud transportation on a steep shelf, Río de la Plata shelf, Puerto Rico: Geo-Marine Letters, v. 2, no. 1-2, p. 71-75.

Kaye, C.A., 1959, Shoreline features and Quaternary shoreline changes, Puerto Rico: U.S. Geological Survey Professional Paper 317-B, p. 49-140.

Malinverno, A., Edwards, M., and Ryan, W.B.F., 1990, Processing of SeaMARC swath sonar data: IEEE (Institute of Electrical and Electronic Engineers) Journal of Ocean Engineering, v. 15 , p. $14-23$.

Mann, P., and Burke, K., 1984, Neotectonics of the Caribbean: Review of Geophysics and Space Physics, v. 22, p. 309 362.
Mayer, L.A., Clarke, J.E.H., and Wells, D., 1993, HYGRO-92 Team, a multi-faceted acoustic ground-truthing experiment in the Bay of Fundy: Proceedings of the Institute of Acoustics, Acoustic Classification and Mapping of the Seabed, v. 15, pt. 2, p. 204-219.

Paskevich, V., 1992, Digital mapping of side-scan sonar data with the Woods Hole Image Processing System software: U.S. Geological Survey Open-File Report 92-536, 87 p.

Pease, M.H., Jr., and Briggs, R.P., 1972, Geologic map of the Rio Grande quadrangle, Puerto Rico: U.S. Geological Survey Miscellaneous Investigations Series Map 1-733, scale 1:20,000, 1 sheet.

Pilkey, O.H., Bush, D.M., and Rodríguez, R.W., 1984, Storm sedimentation: north shelf of Puerto Rico, in Park, Y.A., Pilkey, O.H., and Kim, S.W., eds., Marine geology and physical processes of the Yellow Sea: Proceedings of KoreaU.S. Seminar and Workshop, June 19-23, 1984, Korea Institute of Energy and Resources, Seoul, Korea, p. 242259.

-1987, Bottom sediment types of the northern insular shelf of Puerto Rico: Punta Peñón to Punta Salinas: U.S. Geological Survey Miscellaneous Investigations Series Map I-1861.

Pilkey, O.H., Trumbull, J.V.A., and Bush, D.M., 1978, Equilibrium shelf sedimentation, Río de la Plata shelf, Puerto Rico: Journal of Sedimentary Petrology, v. 48 , no. 2, p. 389400.

Poppe, L.J., Eliason, A.H., and Fredricks, J.J., 1985, APSASan automated particle size analysis system: U.S. Geological Survey Circular 963, p. 1-77.

Rodriguez, R.W., and Webb, R.M.T., 1990, Impact of Hurricane Hugo on coastal resources of Puerto Rico [abs.]: American Association of Petroleum Geologists, 1990 Annual Convention, Official Program, San Francisco, Calif., p. 157.

Rodríguez, R.W., Webb, R.M.T., and Bush, D.M., 1994, Another look at the impact of Hurricane Hugo on the shelf and coastal resources of Puerto Rico: Journal of Coastal Research, v. 10, no. 2, p. 278-296.

Schneidermann, N., Pilkey, O.H., and Saunders, C., 1976, Sedimentation on the Puerto Rico insular shelf: Journal of Sedimentary Petrology, v. 46, no. 1, p. 167-173.

Schwab, W.C., and Rodríguez, R.W., 1992, Progress of studies on the impact of Hurricane Hugo on the coastal resources of Puerto Rico: U.S. Geological Survey Open-File Report 92-717, $169 \mathrm{p}$.

Sykes, L.R., McCann, W.R., and Kafka, A.L., 1982, Motion of the Caribbean plate during the last 7 million years and implications for earlier Cenozoic movements: Journal of Geophysical Research, v. 87, p. 10656-10676.

Thieler, E.R., 1993, Historical shoreline change analysis of Puerto Rico: Durham, N.C., Duke University, unpublished masters thesis, $135 \mathrm{p}$.

Thieler, E.R., and Danforth, W.W., 1993, Historical shoreline analysis in Puerto Rico, 1901-1987: U.S. Geological Survey Open-File Report 93-574, 37 sheets.

Urick, R.J., 1983, Principles of underwater sound for engineers: New York, McGraw-Hill, 3rd Edition, 384 p. 